Against the Wall 
THE CITY IN THE 21ST CENTURY

Eugenie L. Birch and Susan M. Wachter, Series Editors

A complete list of books in the series is available from the publisher. 


\title{
Against the Wall
}

Poor, Young, Black, and Male

\author{
EDITED BY ELIJAH ANDERSON
}

\section{$\overline{\text { PENN }}$}

University of Pennsylvania Press

Philadelphia 
Copyright (C 2008 University of Pennsylvania Press

All rights reserved. Except for brief quotations used for purposes of review or scholarly citation, none of this book may be reproduced in any form by any means without written permission from the publisher.

Published by

University of Pennsylvania Press

Philadelphia, Pennsylvania 19104-4112

Printed in the United States of America on acid-free paper

$\begin{array}{llllllllll}10 & 9 & 8 & 7 & 6 & 5 & 4 & 3 & 2 & 1\end{array}$

A Library of Congress Cataloging-in-Publication record is available from the Library of Congress

ISBN-13: 978-0-8122-2017-9 